DOI: $10.2478 / \mathrm{v} 10014-010-0013-1$

Agrovoc descriptors: sausages,chicken meat,poultry meat,chickens,drug plants,Iran islamic republic,Listeria monocytogenes, essential oils, antimicrobial properties,antibiotic properties

Agris category code: Q03, Q05

\title{
Antimicrobial activity of essential oils of three herbs against Listeria monocytogenes on chicken frankfurters
}

\author{
Abdollah GHASEMI PIRBALOUTI ${ }^{1, *}$, Ebrahim RAHIMI ${ }^{2}$, Sayed Ali MOOSAVI
}

Received July 23, 2009; accepted September 24, 2010.

Delo je prispelo 23. julija 2009, sprejeto 24. septembra 2010.

\begin{abstract}
Listeria monocytogenes is a foodborne pathogen responsible for listeriosis. The inhibitory effect of essential oils $(1 \% \mathrm{v} / \mathrm{w})$ of Thymus daenensis Celak (Lamiaceae), Thymbra spicata L. (Lamiaceae) and Satureja bachtiarica Bunge (Lamiaceae) applied to the surface of chicken frankfurters was determined on L. monocytogenes inoculated at low $\left(10^{3} \mathrm{CFU} / \mathrm{g}\right)$ and high $\left(10^{6} \mathrm{CFU} / \mathrm{g}\right)$ populations and stored for seven and 14 days. The results showed that $L$. monocytogenes populations increased during seven and 14 days of storage at $4{ }^{\circ} \mathrm{C}$ on control frankfurters without essential oil. The application of 1 $\%$ essential oil $(\mathrm{v} / \mathrm{w})$ of herbs to frankfurter surfaces can significantly reduce $(p<0.05)$ the $L$. monocytogenes populations as compared to control in two inocula treatments after seven and 14 days of storage at $4{ }^{\circ} \mathrm{C}$.
\end{abstract}

Key words: Iranian medicinal herbs, Listeria monocytogenes, chicken frankfurters, essential oil

\section{IZVLEČEK}

\section{PROTIMIKROBNA AKTIVNOST ETERIČNIH OLJ TREH ZELIŠČ PROTI PATOGENU Listeria monocytogenes V PIŠČANČJIH HRENOVKAH}

Listeria monocytogenes je povzročitelj listerioze, ki se pojavlja v živilih. Proučevan je bil inhibitorni učinek eteričnih olj $(1 \%$ v/w) zelišč Thymus daenensis Celak (Lamiaceae), Thymbra spicata L. (Lamiaceae) in Satureja bachtiarica Bunge (Lamiaceae), nanešenih na površino piščančjih hrenovk, ki so bile inokulirane z nizko $\left(10^{3} \mathrm{CFU} / \mathrm{g}\right)$ oziroma visoko populacijo $\left(10^{6} \mathrm{CFU} / \mathrm{g}\right)$ listerije ter shranjene za 7 oziroma 14 dni. Rezultati so pokazali, da se populacije $L$. monocytogenes povečajo tekom 7 oziroma 14 dni shranjevanja pri $4{ }^{\circ} \mathrm{C}$ na primerjalnih hrenovkah. Uporaba $1 \%(\mathrm{v} / \mathrm{w})$ eteričnih olj zelišč pri hrenovkah lahko značilno $(p<0.05)$ zmanjša populacijo L. monocytogenes v primerjavi s kontrolo.

Ključne besede: iranska zdravilna zelišča, Listeria monocytogenes, piščančje hrenovke, eterična olja

* Address correspondence to: A. Ghasemi Pirbalouti, Islamic Azad University-Shahrekord Branch, Shahrekord, Iran, POBox: 166. tel: +98 381 3361060, fax: +98 381 3361031, E-mail: ghasemi@iaushk.ac.ir

1 Research Centre of Medicinal Plants and Ethno-veterinary, Islamic Azad University-Shahrekord Branch, POBox: 166, Shahrekord, Iran, Assist Prof., Ph.D., e-mail: ghasemi@iaushk.ac.ir

2 Department of Food Hygiene, School of Veterinary Medicine, Islamic Azad University-Shahrekord Branch, Shahrekord, Iran. Assist Prof., Ph.D.

3 School of Veterinary Medicine, Islamic Azad University-Shahrekord Branch, Shahrekord, Iran. DVM 


\section{INTRODUCTION}

Foodborne illness resulting from consumption of food contaminated with pathogenic bacteria has been of vital concern to public health. Listeria monocytogenes is a Gram-positive bacterium responsible for the severe foodborne illness listeriosis. This disease is primarily transmitted through various foods, fish, dairy products, cured or processed meat, egg, poultry, seafood, salad, fruits and vegetables (Garcia et al., 2004). A severe infection, listeriosis has been associated with a mortality rate as high as 30-40\% (Datta, 2003).

Ready-to-eat (RTE) meat products have been introduced for the convenience of consumers; however, many have few barriers to microbial growth. Frequently, refrigeration is the only barrier for these types of foods, and temperature abuse at any of the links of the supply chain from the processing plants to the consumer's refrigerator could accelerate the growth of $L$. monocytogenes. Most RTE foods receive little or no final heat treatment before being consumed because such foods are assumed to be and are often labelled as fully cooked (Hao et al., 1998). There have been reported illnesses resulting when supposedly RTE foods were not reheated before consumption (Pinner et al., 1992; Schuchat et al., 1991). There have also been a large number of recalls of RTE meat due to contamination by L. monocytogenes (Kathariou, 2000).

To reduce health hazards and economic losses due to foodborne bacteria, the use of natural products as antibacterial compounds seems to be an interesting way to control the presence of pathogenic bacteria and to extend the shelf life of processed food (Dorman and Deans, 2000). Essential (volatile) plant oils occur in edible, medicinal and herbal plants and have been widely used as flavouring agents in foods since the earliest recorded history. It is well-established that many essential oils have antimicrobial activity against a wide range of spoilage and pathogenic bacteria (Deans and Ritchie, 1987; Alzoreky and Nakahara, 2003; Kim et al., 1995).

A lot of references on anti-listeria and antibacterial efficiency of essential oils are available in the literature (Chauhan et al., 2007; Rasooli et al., 2006; Stonsaovapak et al., 2000). For example, Ghasemi Pirbalouti et al., 2009 reported that the essential oil of Thymus daenensis and Thymus sp. flowers exhibited antibacterial activities against $L$. monocytogenes in vitro.

The Iranian medicinal plants, including Thymbra spicata, Satureja bachtiarica and Thymus daenensis have been utilised as spice and culinary plants by the indigenous people of west provinces, Iran (Ghasemi Pirbalouti, 2009).

However, no study investigating the antimicrobial effect of Thymus daenensis, Thymbra spicata and Satureja bachtiarica on L. monocytogenes on RTE chicken frankfurters could be found in the literature surveyed. The objective of this study was to determine the growth inhibition of L. monocytogenes (isolated from chicken meat) on chicken frankfurters and the efficacy of essential oils in inhibiting L. monocytogenes growth on chicken frankfurters.

\section{MATERIALS AND METHODS}

\subsection{Plant material}

The Thymus daenensis Celak (Lamiaceae), Thymbra spicata $\mathrm{L}$ (Lamiaceae) and Satureja bachtiarica Bunge (Lamiaceae) were collected from mountain areas of Zagross, West-South Iran, during May-Nov, 2008. Their identity was confirmed by Ghahraman (1987-1989), Mozaffarian (2007), and Rechinger (1963-1998), and voucher specimens were deposited at the Researches Centre of Medicinal Plants, Islamic Azad University-Shahrekord Branch, Iran.

\subsection{Preparation of Extracts}

The leaves and flowers of plants were powdered $(200 \mathrm{~g})$ and subjected to hydro-distillation (2000 ml distilled water) for $4 \mathrm{~h}$ using a Clevenger-type apparatus according to the method recommended in British Pharmacopoeia (British Pharmacopoeia, 1988). The extracts were filtered using
Whatman No. 1 filter paper and then were stored in universal bottles and refrigerated at $4{ }^{\circ} \mathrm{C}$ prior to use.

\subsection{Food sample preparation}

Chicken frankfurters were purchased at a local supermarket and brought immediately to the laboratory. The frankfurters were cut into $10 \mathrm{~g}$ portions, and the surface of each sample was exposed to UV light $(\lambda=260 \mathrm{~nm})$ for $10 \mathrm{~min}$ to kill surface contaminants.

\subsection{Preparation of Listeria monocytogenes}

The strain of L. monocytogenes was isolated from chicken meat and kindly provided by the Department of Microbiology, Faculty of Veterinary Medicine Faculty, Islamic Azad University- Shahrekord, Iran. Bacterial cultures were maintained frozen in broth at $-20{ }^{\circ} \mathrm{C}$ until use. Prior to use, the 
cultures were activated in at $37{ }^{\circ} \mathrm{C}$ for $24 \mathrm{~h}$. The contents of the tube were transferred to a $100-\mathrm{ml}$ flask containing sterile BHI broth (Merk, Germany) at log phase $\left(\mathrm{OD}_{600}=0.4-0.5\right)$ to scale up the bacterial suspension volume. An initial bacterial suspension containing $1 \times 10^{6} \mathrm{CFU} / \mathrm{ml}$ was made from the flask broth culture.

\subsection{Treatments of food samples}

The inhibitory effect of essential oils $(1 \% \mathrm{v} / \mathrm{w})$ of Thymus daenensis, Thymbra spicata and Satureja bachtiarica applied to the surface of chicken frankfurters (10g of each) was determined after L. monocytogenes was inoculated $(100 \mu \mathrm{l}$ with $10^{3} \mathrm{CFU} / \mathrm{g}$ and $100 \mu \mathrm{l}$ with $10^{6} \mathrm{CFU} / \mathrm{g}$ ) and stored for seven and 14 days at $4^{\circ} \mathrm{C}$. The treated samples were contaminated with $L$. monocytogenes on the surface using a pipette, and then the bacterium was spread with a sterile bent glass rod. A control consisted of chicken frankfurters inoculated with L. monocytogenes with no essential oil. Inoculated samples in Petri-dishes were left undisturbed for 30 min to allow residual moisture to be absorbed. The number of L. monocytogenes on the frankfurters was determined with plate count method at seven and $14\left(\right.$ at $4{ }^{\circ} \mathrm{C}$ ) days of storage. Three replications of the treatments were performed.

\subsection{Microbial analysis}

Three samples from each inoculation level of $L$. monocytogenes at seven and 14 days of storage were assayed $\left(\right.$ at $4{ }^{\circ} \mathrm{C}$ ). Corresponding control samples were also assayed. Samples were serially diluted (1:10), and $100 \mu 1$ was spread plated onto BHI agar (Merk, Germany). The plates were incubated at $37{ }^{\circ} \mathrm{C}$ for $24 \mathrm{~h}$ to determine the population of Listeria. Selected presumptive colonies of L. monocytogenes were confirmed by Henry illumination and biochemical tests (Mytle et al., 2006).

\subsection{Analysis of data}

The numbers of L. monocytogenes was statistically analysed by one ways ANOVA, and statistical significance between treated and control groups was analysed by means of Student's $t$-test $(P$-values $<0.05)$ by the program "SAS version 6.12 full".

\section{RESULTS AND DISCUSSION}

During seven and 14 days of storage of frankfurters, the control samples had higher levels of bacteria than the treated samples $\left(5.3 \times 10^{4} \mathrm{CFU} / \mathrm{g}\right.$ to $\left.7.7 \times 10^{5} \mathrm{CFU} / \mathrm{g}\right)$ (Table 1). The amount of bacteria on the controls was not "increased," but rather, the essential oils prevented bacterial growth on the treated frankfurters. The treatment group had inhibited bacterial growth relative to the growth observed in the control group.

The results indicated that after seven days of storage at $4{ }^{\circ} \mathrm{C}$, essential oil treatments were able to significantly reduced $(p<0.05)$ to $3.2 \times 10$ to $6.6 \times 10^{2} \mathrm{CFU} / \mathrm{g}$, as compared to control $\left(5.3 \times 10^{4} \mathrm{CFU} / \mathrm{g}\right)$ in the frankfurters with low inoculum (Table 1.). The essential oil of Satureja bachtiarica was least efficient in decreasing the L. monocytogenes count with low inoculum after 7 and 14 days at $4{ }^{\circ} \mathrm{C}$, whereas, nitrite and essential oils of Thymus daenensis and Thymbra spicata were highly efficient in decreasing the L. monocytogenes count with low inoculum after 7 and 14 days at $4{ }^{\circ} \mathrm{C}$.

Table 1. Comparison of L. monocytogenes populations in frankfurters treated with different essential oils/plant extracts

\begin{tabular}{ccccc}
\hline \multirow{2}{*}{ Treatments } & \multicolumn{3}{c}{$\mathrm{N}(\mathrm{cfu} / \mathrm{g})$} \\
\cline { 2 - 4 } & \multicolumn{2}{c}{ Low inoculum } & \multicolumn{2}{c}{ High inoculum } \\
\cline { 2 - 4 } & $5.3 \times 10^{4} \mathrm{a}$ & $7.7 \times 10^{5}$ & $5.3 \times 10^{7}$ & $5.7 \times 10^{8}$ \\
\hline Control & $3.2 \times 10^{*}$ & $4.7 \times 10^{*}$ & $3.7 \times 10^{3} *$ & $3.8 \times 10^{2} *$ \\
Thymus daenensis & $6.5 \times 10^{*}$ & $3.1 \times 10^{*}$ & $6.5 \times 10^{3} *$ & $5.4 \times 10^{3} *$ \\
Thymbra spicata & $6.6 \times 10^{2} *$ & $4.8 \times 10^{*}$ & $4.9 \times 10^{4} *$ & $6.1 \times 10^{4} *$ \\
Satureja bachtiarica &
\end{tabular}

a: Statistically significant by Student's $t$-test, $N=3$ samples.

*: $P \leq 0.05$ levels of significance.

During 7 and 14 days of storage of control frankfurters (without essential oil) with high inoculum at $4{ }^{\circ} \mathrm{C}, L$. monocytogenes reached to $5.3 \times 10^{7}$ to $5.7 \times 10^{8} \mathrm{CFU} / \mathrm{g}$ (Table 1.).

The results showed that essential oil treatments were able to significantly reduced $(p<0.05)$ to $3.7 \times 10^{3}$ to 4.9 x $10^{4} \mathrm{CFU} / \mathrm{g}$, as compared to control $\left(5.3 \times 10^{7} \mathrm{CFU} / \mathrm{g}\right)$ with high inoculum after 7 days of storage at $4{ }^{\circ} \mathrm{C}$. After 7 and 14 days at $4{ }^{\circ} \mathrm{C}$, the essential oil of Satureja bachtiarica was least efficient at decreasing the $L$. monocytogenes count on frankfurters that received the high inoculum treatment, whereas the essential oil of Thymus daenensis was highly efficient at decreasing the 
L. monocytogenes count on frankfurters with high inoculum.

The most active constituents (essential oils) of many spices have a wide spectrum of antimicrobial activity including aromatic phenolic compounds, such as thymol and carvacrol in oregano and thyme, eugenol in clove and cinnamon, and cinnamic aldehyde in cinnamon (Beuchat and Golden, 1989). These bioactive principles in the related dietary spices and medicinal herbs were also identified in other studies (Chauhan et al., 2007; Zampini et al., 2005). Some studies claim that the phenolic compounds present in spices and herbs might also play a major role in their antimicrobial effects (Hara-Kudo et al., 2004).

Shan et al. (2007) showed that many herb and spice extracts contained high levels of phenolics and exhibited antibacterial activity against foodborne pathogens. Gram-positive bacteria such as $L$. monocytogenes were generally more sensitive to the tested extracts than Gram-negative ones. Also, Shan et al. (2007) reported a highly positive relationship $\left(\mathrm{R}^{2}=0.73\right)$ between antibacterial activity and phenolic content of the tested extracts against $L$. monocytogenes. According to a report of Rasooli et al. (2006), various concentrations of essential oils from Thymus eriocalyx and Thymus x-porlock tested on agar plates and in broth tubes showed very strong anti-listeria properties. Also, they reported that Thymus x-porlock was a stronger bactericidal agent than Thymus eriocalyx oil. Rožman and Jeršek (2009) confirmed that antimicrobial activity of rosemary (Rosmarinus officinalis L.) extracts was depended on selected rosemary extract, concentration of extracts, different species of Listeria and different strains of Listeria monocytogenes.
The essential oil and extract of some aromatic plants (for example, the mint family, Lamiaceae) with a higher percentage of carvacrol and thymol have a higher efficacy against bacterial strains (Rasooli et al., 2006). The essential oils of Thymus daenensis (Nickavar et al., 2005), Thymbra spicata (Hanci et al., 2003) and Satureja bachtiarica (Sefidkon et al., 2007) contained high levels of phenolics monoterpenes (thymol and carvacrol) and exhibited antibacterial activity. They could be a potential source of inhibitory substances against some foodborne pathogens as well as a source of antioxidant agents.

Hao et al. (1998) applied extracts of various plants, including clove oil, to cooked chicken to determine their antimicrobial activity against the Scott A strain of $L$. monocytogenes. They reported no growth of the test strain of Listeria at $5{ }^{\circ} \mathrm{C}$ in untreated samples when a high population of $10^{5} \mathrm{CFU} / \mathrm{g}$ inoculum was applied. In our study, the essential oil treatments significantly reduced the final L. monocytogenes populations after 7 and 14 days of storage at $4{ }^{\circ} \mathrm{C}$ as compared to the control.

Yuste and Fung, 2002 determined that $0.1 \%$ cinnamon reduced $10^{4} \mathrm{CFU} / \mathrm{g}$ of $L$. monocytogenes Scott A in pasteurised apple juice $(\mathrm{pH}=5.0)$ to undetectable cell numbers within $1 \mathrm{~h}$ of storage at $5{ }^{\circ} \mathrm{C}$ and $20^{\circ} \mathrm{C}$. In this study, the inhibitory effect of species of thyme on $L$. monocytogenes varied during storage for the same treatment. Mytle et al. (2006) reported that the application of $1 \%$ clove oil (v/w) to frankfurter surfaces or the inclusion of cloves or clove oil in the frankfurters, coupled with low temperature storage, can reduce the potential of $L$. monocytogenes contamination and growth without significantly changing flavour.

\section{CONCLUSIONS}

In conclusion, the L. monocytogenes populations in frankfurters treated with essential oils were significantly lower than in control samples throughout the storage period. The application of $1 \%$ thyme oil $(\mathrm{v} / \mathrm{w})$ applied to the surface of chicken frankfurters coupled with low temperature storage can reduce the potential of $L$. monocytogenes contamination.

In this study, the essential oils with high anti-listeria activity may be candidates for future studies of synergism, compatibility, and activity in foods or foodprocessing systems and mechanisms of activity against specific pathogens. The tested plant extracts may contain antimicrobial constituents, and further phytochemical and pharmacological studies will be necessary to isolate the active constituents and evaluate the antimicrobial activity against a wide range of microbial populations.

\section{REFERENCES}

Alzoreky, N.S., Nakahara, K., 2003. Antimicrobial activity of extracts from some edible plants commonly consumed in Asia. Int J. Food Microbiol. 80, 223-230.
Beuchat, L.R., Golden, D.A., 1989. Antimicrobials occurring naturally in foods. Food Technol-Chicago. 43, 134-142. 
British Pharmacopoeia, 1988. (Vol. 2, pp. 137-138). London: HMSO.

Chauhan, A.T., Negi, P.S., Ramteke, R.S., 2007. Antioxidant and antibacterial activities of aqueous extract of Seabuckthorn (Hippophae rhamnoides) seeds. Fitoterapia, 78, 590-592.

Datta, A.R., 2003. Listeria monocytogenes. In M. D. Miliotis \& J. W. Bier (Eds.), International handbook of foodborne pathogens (pp. 105-121). New York: Marcel Dekker Inc.

Deans, S.G., Ritchie, G., 1987. Antibacterial properties of plant essential oils. Int. J. Food Microbiol. 5, 165-180.

Dorman, H.J.D., Deans, S.G., 2000. Antimicrobial agents from plants: antimicrobial activity of plant volatile oils. J. Appl Microb. 88, 308-316.

Garcia, M.T., Canamero, M.M., Lucas, R., Omar, N.B., Pulido, R.P., Galvez, A., 2004. Inhibition of Listeria monocytogenes by enterocin EJ97 produced by Enterococcus faecalis EJ97. Int. J. Food Microbiol. 90, $161-170$

Ghahreman, A., 1987-1989. Flora of Iran, Department of Botany, Institute of and Rangelands Press, Tehran (in Persian).

Ghasemi Pirbalouti, A., 2009. Medicinal plants used in Chaharmahal and Bakhtyari districts, Iran. Herba Polon. $55,69-75$.

Ghasemi Pirbalouti, A., Roshan-Chaleshtori, A., Tajbakhsh, E., Momtaz, H., Shahin, F., 2009. Bioactivity of Iranian medicinal plants against Listeria monocytogenes isolated from food. J. Food. Agri. Environ. 7, 66-69.

Hao, Y.Y., Brackett, R.E., Doyle, M.P., 1998. Efficacy of plant extracts in inhibiting Aeromonas hydrophila and Listeria monocytogenes in refrigerated, cooked poultry. Food Microbiol. 15, 367-378.

Hanci, S., Sahin, S., Y1lmaz, L., 2003. Isolation of volatile oil from thyme (Thymbra spicata) by steam distillation. Nahrung. 47, $252-255$.

Hara-Kudo, Y., Kobayashi, A., Sugita-Konishi, Y., Kondo, K., 2004. Antibacterial activity of plants used in cooking for aroma and taste. J. Food Protect. 67, 2820-2824.

Kathariou, S., 2000. Pathogenesis determinants of Listeria monocytogenes. In J. W. Cary, J. E. Linz, \& D. Bhatnagar (Eds.), Microbial foodborne diseases, mechanisms of pathogenesis and toxin synthesis (pp. 295-314). Lancaster, Pa: Technomics Publ. Co., Inc.

Kim, J., Marshall, M.R., Wie, C., 1995. Antibacterial activity of some essential oil components against five foodborne pathogens. J. Agr. Food Chem. 43, 2839-2845.

Mozaffarian, V., 1996. Encyclopedia of Iranian Plants. Farhang Moaser Publication, Tehran, Iran, 671 pp. (in Persian).
Mytle, N., Anderson, G.L., Doyle, M.P., Smith, M.A., 2006. Antimicrobial activity of clove (Syzgium aromaticum) oil in inhibiting Listeria monocytogenes on chicken frankfurters. Food Control. 17, 102-107.

Nickavar, B., Mojab, F., Dolat-Abadi, R., 2005. Analysis of the essential oils of two Thymus species from Iran. Food Chem. 90, 609-611.

Pinner, R.W., Schuchat, A., Swaminathan, B., Hayes, P.S., Deaver, K.A., Weaver, R.E., Plikaytis, B.D., Reeves, M., Broome, C.V., Wenger, J.D., 1992. Role of foods in sporadic listeriosis. II. Microbiologic and epidemiologic investigation. The Listeria study group. J. Amer Med. Assoc. 267, 2046-2050.

Rasooli, I., Rezaei, M.B., Allameh, A., 2006. Ultrastructural studies on antimicrobial efficacy of thyme essential oils on Listeria monocytogenes. Int. J. Infect. Dis. 10, 236241 .

Rechinger, K.H., 1963-1998. Flora Iranica. Vol. 1-173. Austria, Graz: Akademische Druck und Verlagsanstalt.

Rožman T., Jeršek B. 2009. Antimicrobial activity of rosemary extracts (Rosmarinus officinalis L.) against different species of Listeria. Acta agriculturae Slovenica, 93: $51-58$

Schuchat, A., Swaminathan, B., Broome, C.V., 1991. Epidemiology of human listeriosis. Clin. Microbiol. Rev. 4, 169-183.

Sefidkon, F., Sadeghzadeh, L., Teimouri, M., Asgari, F., Ahmadi, S., 2007. Antimicrobial effects of the essential oils of two Satureja species (S. khuzistanica Jamzad and $S$. bachtiarica Bunge.) in two harvesting time. J. Med. Aromat. Plant Sci. 23, 174-182 (in Persian).

Shan, B., Cai, Y.Z., Sun, M., Corke, H., 2005. Antioxidant capacity of 26 spice extracts and characterization of their phenolic constituents. J. Agr. Food Chem. 53, 7749-7759.

Shan, B., Cai, Y., Brooks, J.D., Corke, H., 2007. The in vitro antibacterial activity of dietary spice and medicinal herb extracts. Int. J. Food Microbiol. 117, 112-119.

Stonsaovapak, S., Chareonthamawat, P., Boonyaratanakornkit, M., 2000. Inhibitory Effects of Selected Thai Spices and Medicinal Plants on Escherichia coli O157: H 7 and Yersinia enterocolitica. Kasetsart J. (Nat. Sci.), 34, 510517.

Yuste, J., Fung, D. Y. C., 2002. Inactivation of Listeria monocytogenes Scott A 49594 in apple juice supplemented with cinnamon. J. Food Protect. 65, 16631666.

Zampini, I.C., Vattuone, M.A., Isla, M.I., 2005. Antibacterial activity of Zuccagnia punctata Cav. ethanolic extracts. J. Ethnopharmacol. 102, 450-456. 